\title{
Change and Continuity: The Bureaucracy of Knowledge in South America
}

\author{
Irina Podgorny
}

Much of nineteenth-century historiography affirmed the idea, spread during the Spanish American Revolution and Independence period that the metropolis had abandoned its former territories to a state of darkness in terms of science. ${ }^{1}$ Paradoxically, this understanding was consolidated thanks to the very nature of the most important innovations implemented by the Spanish monarchy: the technology of long-distance government, bureaucracy, and the archive, and, within this framework, the secretive nature of the administration of the Indies. ${ }^{2}$

Over the past thirty years, Spanish and Mexican scientific historians have reversed this vision, studying the dynamics of the expeditions sponsored by the Crown and the enormous quantity of materials about the three kingdoms of nature that were collected in the Royal Cabinet, the Royal Pharmacy of Madrid, and the cabinets created in major cities of the viceroyalties during the last third of the eighteenth century. An analysis of the products from the Indies in medicine, commerce, and mining as well as the envoy of experts to the area reveals a history of knowledge as long and complex as those of the Dutch or British. $^{3}$

1 This chapter was previously published in a similar form: "Bureaucracy, Instructions, and Paperwork: The Gathering of Data about the Three Kingdoms of Nature in the Americas, 1770-1815," Nuevo Mundo Mundos Nuevos [Online], Paper posted on February 19, 2019. https:// doi.org/10.400o/nuevomundo.75454. The text has been adapted to the reflections developed in this volume.

2 During the period from 1810 to 1826 , the political map of Spanish America was redrawn by the process of liberation from colonial rule triggered by the Napoleonic wars. In the Rio de la Plata Provinces, Independence was declared in 1816.

3 From studies of the work of Francisco Hernández (physician to Felipe II), the business of Nicolás Monardes in Seville, the royal expeditions of the eighteenth and early nineteenth centuries (Royal Botanical Expedition, Royal Antiquities Expedition, Ulloa's expedition), and even the border missions, contemporary bibliography acknowledges the mobilization of resources and individuals to study the Indies. These topics, developed first in the work of José María López Piñero, his students and collaborators, and then that of Juan Pimentel, Antonio Lafuente, and Nuria Valverde, have recently been rediscovered by US-American researchers.

(C) IRINA PODGORNY, 2022 | DOI:10.1163/9789004412477_007

This is an open access chapter distributed under the terms of the CC BY-NC 4.o license. Podgorny - 9789004412477 
That earlier historiographical notion ignored not only the series of dispositions from Madrid to gather data about the nature and commerce of the Americas, but also - and more importantly for our argument - the continuity between the "old" ways of the Spanish Empire and the new dispositions by American revolutionary governments. Indeed, the discourse on the rupture of the colonial order and the history of new scientific and academic institutions often forgets that the agents in charge of describing the natural and social American world changed flags, but not names or interests. The same priests, physicians, topographers, pilots, and engineers who botanized, made maps, and gathered insects and meteorological data before Independence then swore loyalty to the new Republics and used the same methodology to continue their work, trying with varying degrees of success to find a state who would sponsor them. ${ }^{4}$ In doing so, intentionally or not, they brought the practices and knowledge learned in the academies, schools, and administrative offices of the late colonial Ibero-American world to the new political order.

By observing several episodes during the late colonial period and the early decades of the nineteenth century, this paper describes this system of production and circulation of knowledge linked to bureaucracy and the Atlantic trade. Based on primary sources from the General Archive of the Indies, the General Archive of the Nation (Argentina), the Archive of the Royal College of Surgeons (London), and on secondary bibliography, in particular the work of Javier I Sánchez Almazán on Pedro Franco Dávila's Instructions for the Royal Cabinet of Madrid, this chapter, rather than focusing on the objects collected, considers the documents that resulted from the "necessity" of collecting minerals, plants and animals. In this way, it reveals the true protagonists of this story: the pathways of bureaucracy and the flow of paperwork where data about nature and man in the Americas were generated and took shape. There, on official stationery, the instructions and networks established by the offices for remote governance would appear along with yet unknown animals, plants, rivers, ancient cities and islands. What expectations did this world of papers and bureaucracy create so that the agents of the royal service would go out to collect plants, minerals, and animals? This question becomes more significant after the overthrow of the colonial administration because these people continued with the same activities despite the fact that those expectations could no longer be met.

To consider these topics, this article will examine the instructions for the collection of samples from the natural world written before and after the process

4 Jorge Gelman, Un funcionario en busca del Estado-Pedro Andrés García y la cuestión agraria bonaerense, 1810-1822 (Buenos Aires: Universidad Nacional de Quilmes, 1997). 
of Independence. In particular, it will discuss those related to the provision of the Royal Cabinet of Madrid (1776), which illustrate how the history of natural history practices articulates the history of the sovereign's political curiosity (to know and control "everything") and the interests of those individuals who, as Arndt Brendecke recalls, appeal to this curiosity to combine the promise of new knowledge with the opportunity to promote their own projects. The history of these instructions also illuminates how the interests and expectations of those individuals are shaped by the practices in which they are immersed and how the instructions become independent of their "author" and continue to impact other institutions and subjectivities. In this sense, the instructions, as forms of bureaucracy, defy any attempt to assign them to a certain historical period based on the ruptures of political order, and instead demonstrate the continual recombination of knowledge and patterns from different domains and moments in time. Thus, this chapter refers to those contingent contexts beneficial to collecting activities that help to learn about a certain territory.

\section{Instructions}

In 1771, after various failed attempts, Pedro Franco Dávila (1711-1786) was able to persuade Carlos III to establish a Royal Cabinet of Natural History in Madrid with the objects he and Pedro Vicente Maldonado had collected in the Old and New Worlds. ${ }^{5}$ Dávila, the son of a cacao producer from Guayaquil, had lived with his collections in Paris since 1745. Trained in the rules of Spanish commerce, he had visited ports and regions throughout the Americas, becoming familiar with the procedures that characterized overseas transport control. Once established in Europe, he maintained contact with family members overseas, other residents of Nueva Granada, and several European academics with whom he exchanged data, favours and objects.

The Royal Cabinet was inaugurated in November 1776, in the context of the so-called Bourbon reforms, which mobilized plants, antiquities, and animals

5 Juan Pimentel, Testigos del Mundo: Ciencia, literatura y viajes en la ilustración (Madrid: Marcial Pons, 2003); Javier I. Sánchez Almazán, Pedro Franco Dávila (1711-1786): De Guayaquil a la Royal Society. La época y la obra de un ilustrado criollo (Madrid: CSIC, 2012); Miguel Villena Sánchez-Valero et al., El gabinete perdido: Pedro Franco Dávila y la historia natural del Siglo de las Luces (Madrid: CSIC, 2009); Maria Ángeles Calatayud Arinero, Catálogo crítico de los documentos del Real Gabinete de Historia Natural (1787-1815) (Madrid: CSIC, 2000); Agustín Jesús Barreiro, El Museo Nacional de Ciencias Naturales (1771-1935) (Madrid: Doce Calles, 1992 [1944]). On Maldonado's collections, see Neil Safier, Measuring the New World:Enlightenment Science and South America (Chicago, London: The University of Chicago Press, 20o8), 167-68. 
to Madrid. These reforms also fuelled the flow of paper that characterized Spain's administration of their marine territories since the Habsburgs, when long distance government required them to incorporate written documents and a bureaucratic structure that compensated for king's to be physically present in the new territories. In the sixteenth century, the Council of Indies promoted the description of the New World through instructions and questionnaires and, starting in the 1570s, reports had to follow a series of questions to be answered on site. ${ }^{6}$ After the reforms of Juan de Ovando during Felipe II's reign, every American bureaucrat was duty-bound to permanently describe the overseas Spanish territories. In this sense, the instructions, charts, and surveys were a means to construct a common space of knowledge. ${ }^{7}$ These procedures aimed at educating the traveller and guiding them in the collection of data and objects or in the use of instruments. When the Bourbons in the eighteenth century reformulated these instructions, they tried to perfect those of Ovando, combining them with new interests and placing the collection of objects in a public or semi-public space (represented by the Royal Cabinet or Royal Pharmacy).

Thus, in May 1776, Joseph de Gálvez y Gallardo, newly designated Secretary of State of the Universal Office of the Indies, had the "Royal Order notice for the remission of Natural History curiosities to the Royal Cabinet" (1776-1777) printed and circulated, accompanied by the following note:

The King has established in Madrid a Cabinet of Natural History in which the Animals, Vegetables, Minerals, rare Stones and whatever Nature

6 Jose María López Piñero, El arte de navegar en la España del Renacimiento (Madrid: Labor, 1979), 83-97.

7 Bernhard Siegert, Passagiere und Papiere: Schreibakte auf der Schwelle zwischen Spanien und Amerika (München: W. Fink, 2006); Wolfgang Schäffner, "Die Verwaltung der Endlichkeit: Zur Geburt des neuzeitlichen Romans in Spanien," in Die Endlichkeit der Literatur, ed. Eckart Goebel and Martin von Koppenfels (Berlin: Akademie Verlag, 2002), 1-12; Arndt Brendecke, Imperium und Empirie: Funktionen des Wissens in der Spanischen Kolonialherrschaft (Köln, 20o9); also Guillaume Gaudin, Penser et gouverner le nouveau monde au XVII siècle: l'empire de papier de Juan Diez de la Calle, commis du Conseil des Indes (Paris: L'Harmattan, 2013). At the same time, the famous Methodus apodemica was developed in works such as those of Theodor Zwinger (Basel, 1577), see Irina Podgorny and Wolfgang Schäffner, "La intención de observar abre los ojos," Prismas 4 (2000): 218. In England, the first of these instructions, in the form of a traveller's survey, dates back to the second half of the seventeenth century. It was continued in the eighteenth century by various European academics and learned societies. See Marie-Noëlle Bourguet, "La collecte du monde: voyage et histoire naturelle (fin XVIIème siècle - début XIX ${ }^{\text {ème }}$ siècle)," in Le Muséum au premier siècle de son histoire, ed. Claude Blanckaert et al. (Paris: Muséum National d'Histoire Naturelle, 1997). See Simona Boscani Leoni's article in this volume. 
produces in his Majesty's vast Domains will be gathered, as well as whatever is possible to acquire from strange lands. To complete and enrich the series and collections of the Royal Museum in each one of its classes, it is necessary that the subjects who govern in the Provinces and Towns of the Spanish Kingdoms, now and in the future take care to gather any curious pieces that they find in their districts and send them to the Cabinet to Natural History.

Hereby including you in His Majesty's order for your intelligence and completion in the part that involves you, persuading you that the King will look at your performance of this order as singular proof of the zeal of your service and love of the public good and so that you personally understand what curiosities are desired and the manner of their conservation, I include copies of the Instruction so that this effort that the King has ordered is extended, leaving it to you to distribute them to the subjects that are concerned with this effort, without having to limit this only to Justices of the Towns, it could also include Priests and other individual people who you choose and will be able to accurately carry this out.

Finally, I express to you that the King wants those who follow you in this position to continue to take care to collect and send the rare pieces that are discovered so that in this way, the different series of the Cabinet in the three Kingdoms of Nature will be completed and renovated, avoiding that such an important and useful establishment will fall apart. ${ }^{8}$

As Susan Socolow signaled several years ago, the "love of Royal Service," spread throughout the channels and networks created by the post and the body of civil servants, and included a series of characters whose biographies can barely be traced beyond the papers that they once signed or sent. ${ }^{9}$ An instruction, like the one meant to enrich the Royal Cabinet, arrived for the viceroys or governors who were then supposed to retransmit it throughout their geographical space via judiciary officials, priests, and anyone else necessary to meet the order's objective, in a network already defined by Ovando's instructions. Moreover, the instruction was supposed to be maintained through time, left in place so subsequent groups of civil servants would also comply with it.

8 "Real Orden circular para la remisión de curiosidades de Historia Natural para el Real Gabinete, ejemplares de la instrucción (1776-7)", Indiferente General, folio 669 (Archivo General de Indias). My translation. See Ernesto Lemoine Villicaña, "Instrucciones para aumentar las colecciones del gabinete de historia natural de Madrid," Boletín del Archivo General de la Nación 2, no. 2 (1961).

9 Susan Socolow, The Bureaucrats of Buenos Aires, 1769-1810: Amor al Real Servicio (Durham: Duke University Press, 1987). 
As long as the instruction was not cancelled, it continued to act and model practices, subjectivities, customs, objects, and papers. This explains why the governor of Buenos Aires, Juan José de Vértiz, responded from Montevideo on September 28, 1776, "offering to collect and direct when appropriate": the five copies of the instruction were in his power "with the care to proceed with the mere correspondence of complying with his Majesty's orders in all its parts," that is, to procure the animals, plants and minerals whose presence was required in Madrid and pack and prepare them in such a way that they arrive at their destination. ${ }^{10}$

The instructions that Gálvez circulated were not based as much on the King's personal desire as they were on a draft elaborated by Pedro Franco Dávila, who had been named in 1771 as lifetime director of the Royal Cabinet of Madrid." In February 1776, with the cabinet already open to the public, Dávila wrote a "List so that the Viceroys, Governors, Chief Magistrates, Mayors and Provincial Superintendents in all of His Majesty's Domains can make, collect, prepare and send to Madrid all of Nature's productions that they find in the lands and towns of their districts." There, he detailed the minerals, plants, and animals of the Indies with which he was familiar through his own experience, literary references and/or observation of the collections held in Parisian cabinets, indicating the places where they should be sought and their equivalents in the Old World. The definitive instructions received by the viceroys added and omitted species and included the request for "petrified objects" and "curiosities of art" (dresses, weapons, instruments, furniture, machines, and idols).

Dávila is a good example of how an individual collector was able to move into the royal domain with that collection; later, as director of the cabinet, he utilized the Crown's communication and governmental structure to expand a collection that was linked to his own identity, an identity shaped by the practices of both bureaucracy and commerce. Dávila combined these practices with the catalogues that described the natural history cabinets proliferating in Paris and with the lists of merchandise transported by ships. Thus, the instructions that he wrote are similar to others produced in eighteenth-century Spain that were still valid at the time, such as those written in Aranjuez on June 6, 1752, and sent to the viceroys of Mexico, Lima, and the Kingdom of New

10 Bourguet, "La collecte"; María Eugenia Constantino and Antonio Lafuente, "The Hidden Logistics of Longinos's Novohispanic Cabinet," Nuncius 27, no. 2 (2012), and Marcelo F. Figueroa, "Packing Techniques and Political Obedience as Scientific Issues: 18th-Century Medicinal Balsams, Gums and Resins from the Indies to Madrid," HOST 5 (2012).

11 Sánchez Almazán, Pedro Franco Dávila, 23-145. This whole section is based on that work and on Lemoine Villicaña, "Instrucciones." My translation. 
Granada for the collection of all types of natural products and the building of a "Royal Cabinet of Natural History of the Mines that were found in the domains of His Majesty in America."

In this way, the instructions and the formalisms of commerce and traffic across the Atlantic produced a flow of objects while also reinforcing each other, thereby generating new forms and subjectivities that incorporated state bureaucracy and commercial registers into how the world and nature were ordered. As Jakob Tanner has underscored, this is about the "performing power" of bureaucracy and its "archive."12 Thanks to these protocols, "unknown" things could be seen, such as the ancient houses of the ruins of Palenque in Chiapas or the "rare and corpulent animal" of the Luján River. ${ }^{13}$ Moreover, they created a way for some priests, military engineers, governors, mayors, and viceroys in the overseas territories to take advantage of them so that through a skeleton, mineral or plant, they could draw attention to the ordinary and extraordinary productions of their lands as well as to their own loyalty and devotion to the Crown. ${ }^{14}$

\section{The Skeleton of Luján}

The instructions, as previously mentioned, indicated that every viceroy should send things revealed or discovered in the territories they governed back to Madrid. Thus, in 1788, the Viceroy of Buenos Aires, the Marquis of Loreto, accompanied a shipment of objects with two documents for Minister Porlier: one, dated in March, attached the design "in parts and according to how it should look after the skeleton is put together" of a very corpulent and unknown animal, and announced that the bones would follow in a future shipment. The other, from May, ratified the first and was a guide to the shipment of seven boxes on board the mail Frigate la Cantabria. In those letters, the Marquis reported:

12 Jakob Tanner, "Akteure, Akten und Archive," in Was Akten bewirken können: Integrationsund Ausschlussprozesse eines Verwaltungsvorgangs, ed. Claudia Kaufmann and Walter Leimgruber (Zurich: Seismo, 2008).

13 Irina Podgorny, "The Reliability of the Ruins," Journal of Spanish Cultural Studies 8, no. 2 (2007).

14 Until now, no one has studied whether these packages received any type of compensation that responded to the expectations of the person who sent the novelties. However, I understand it to be within the same system as the gifts, donations, and favours analysed by Viviana L. Grieco, The Politics of Giving in the Viceroyalty of Rio de la Plata: Donors, Lenders, Subjects, and Citizens (Albuquerque: The University of New Mexico Press, 2014). 
Don Manuel Warnes first Alcalde of this city informs us that Brother Manuel de Torres of the Order of Predicadores has discovered the skeleton of a corpulent animal chiefly unknown in this part of America, where no species is to be found that it could be compared to, adding besides that the friar intended to acquaint me of it. I immediately decided to hear him, upon which, by his mere narrative I found the discovery to be a valuable one and that it might also help to prove erroneous the belief some had entertained in previous occasions when some loose bones happened to have been found that they belonged to the human species notwithstanding the enormous stature they were supposed and I determined therefore that this skeleton should be dug up from the place in which it was found and should be brought to my abode in the fort with the least possible damage, because the dampness of the soil caused some the parts to be very apt to mold of, especially the head and ribs.

All this was carefully entrusted to the said Friar [...], I have determined all to be packed up in seven cases, that as they must necessarily be large on account of the size of some of the bones and the great amount of the straw necessary for their preservation if they were to be reduced to a smaller number would make it more difficult to be transported.

In each of the cases the contents are labeled in conformity with what is expressed and numbered in the first leaf of the annexed memorandum. The second leaf shrews the figure that it is supposed to have if joined together and in this leaf notations are made on the place in which the discovery took place and the inferences made to consider it as a novelty compared with other known animals.

Lately some of the Caciques or chiefs of the infidels of the pampa and the Sierra have happened to come to this city. I took care they should see these bones in the manner they had been placed in order to complete the shape of this animal, and they seemed to be astonished asserting afterwards they could not be of this country as they had no knowledge of them and they had always been under the belief that some bones that had been found belonged to their forefathers. But it is very natural to infer that the latter if the animal were mischievous and not numerous should have destroyed them when they were the sole possessors of this land. ${ }^{15}$

15 This is a translation of Spanish papers purchased in Seville c. 1833, when the remaining furniture from the Marquis of Loreto's house was sold after a fire on July 17, 1827, had destroyed most of the property's valuable items. The translation was sent by Manuel Williams, son of Julian Benjamin Williams, British Vice Consul in Seville, and an active dealer in Spanish works of art, to the Royal College of Surgeons Archives where it was kept in their file on Megatherium; see Vicente Lleó Cañal, "Julian Benjamin Williams y el 
Friar Manuel Torres - one of the many agents who responded to the instructions - made his discovery of enormous bones on the Luján River, about five miles from the town of the same name and about sixty kilometres from Buenos Aires. Prior to removing the bones, the friar requested that the viceroy send a draughtsman to "extract them to paper," for all the work might be otherwise ruined. The Marquis of Loreto granted the request and further ordered that the articulations and parts in the picture also be numbered in order to identify the corresponding bone. The dimensions were to be taken and the skeleton described in detail, giving the name and distance from the nearest town and to the Río de la Plata. The skeleton was so immense that speculation began as to what the animal's body mass might have been with flesh and hide. Until that time, there had been no other reports in the Americas of a creature with similar characteristics, and it was not known whether this was an amphibious or aquatic animal, although it was assumed to be terrestrial based on the size of its nails. It bore no resemblance to the elephant, except in terms of size, nor to the rhinoceros or the anta, namely the South American tapir. However, animal bones had been found in the vicinity from smaller specimens of these same species. The gigantic bones were packed in hides and sent to Buenos Aires, where several experts reassembled them as a mounted skeleton. Finally, they were shipped off to Madrid in seven boxes, where the Royal Cabinet preparers submitted the skeleton for exhibition. ${ }^{16}$ (Fig. $6.1 \mathrm{a}$, b and c)

The drawings, signed by the lieutenant Francisco Pizarro, draftsman of the Royal Body of Artillerymen, combined the discoverer's desires with the viceroy's instructions. The viceroyalty's bureaucracy, as seen in the official letters, sent off the bones and the drawings, leaving copies in the Buenos Aires archive. All of the people involved were instilled with the importance of the instructions and with their devotion to the Royal Service, which in addition to producing papers, also created and made visible new objects, giving potential to new searches. The Marquis sent the seven boxes to Galicia and then Madrid, where the Royal Cabinet preparers mounted it for exhibition. When the King was apprised of this, he reportedly requested a "live or stuffed" specimen of the rare, corpulent animal, a sketch of which eventually ended up in the hands of Georges Cuvier. Based on this, in the comparative anatomy laboratories of Paris, the Beast of Luján would be classified as belonging to a new genus:

comercio de arte en la Sevilla del XIX," Boletín de la Real academia Sevillana de Buenas Letras: Minervae Baeticae 36 (2008). The original document in Spanish is kept in the Archivo General de Indias, Indiferente General, Buenos Aires, 76, folio 31, Buenos Ayres, 2 de marzo de 1788, "Remesa de osamentas de un animal mui corpulento".

16 Manuel R. Trelles, "El Padre Manuel Torres," Revista de la Biblioteca Pública de Buenos Aires 4 (1882). 

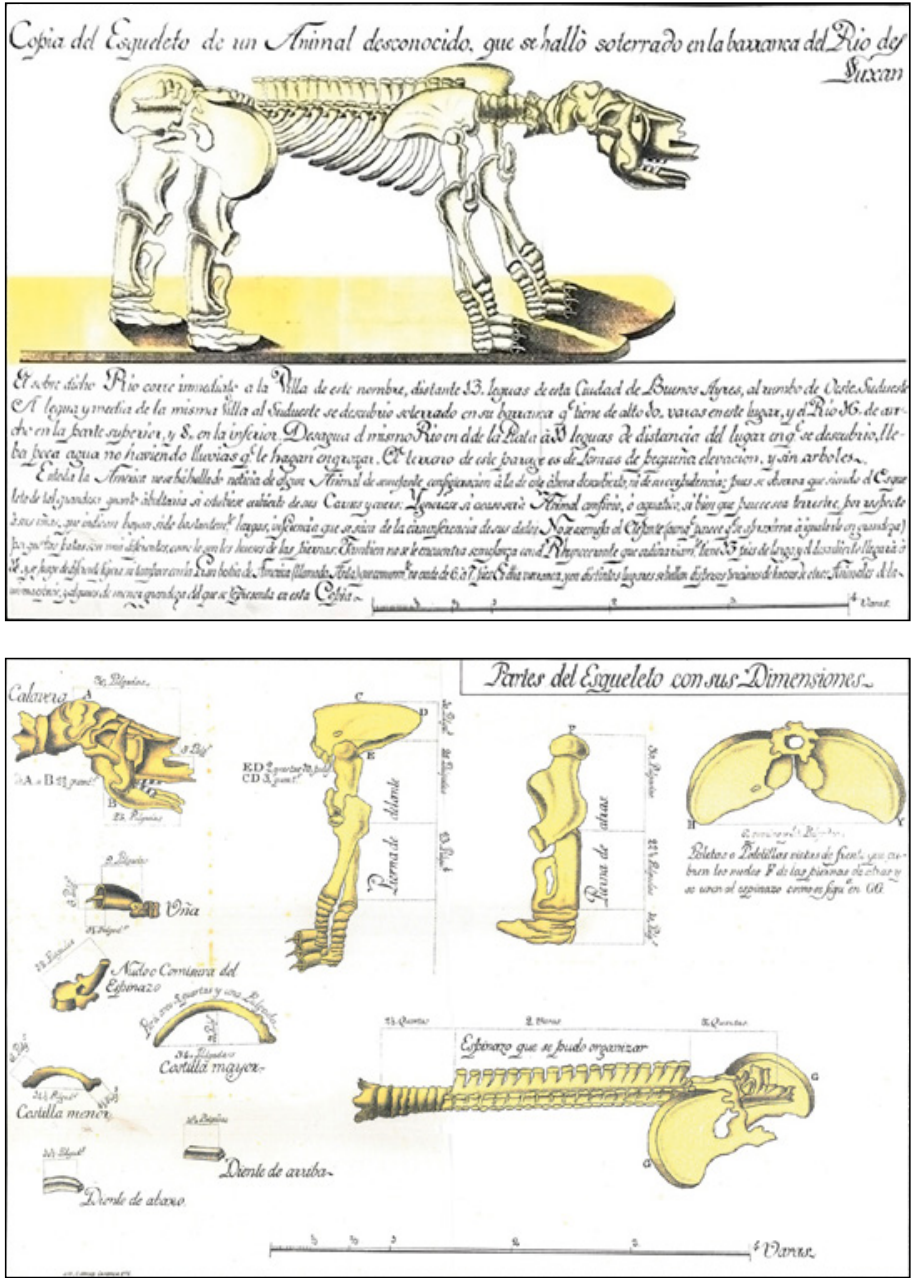

Niomen. Lev, Dimentions, y entriat an

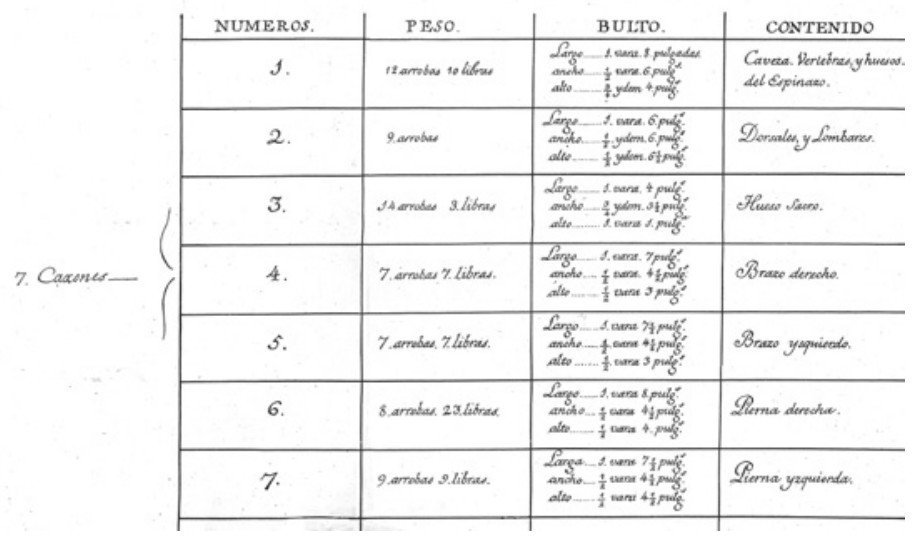

FIGURE 6.1

Paperwork accompanying the shipment to Spain of the skeleton of the mighty animal, as printed in Manuel R. Trelles, "ElPadre Manuel Torres," Revista de la Biblioteca Pública de Buenos Aires, 1882, vol. 4, 


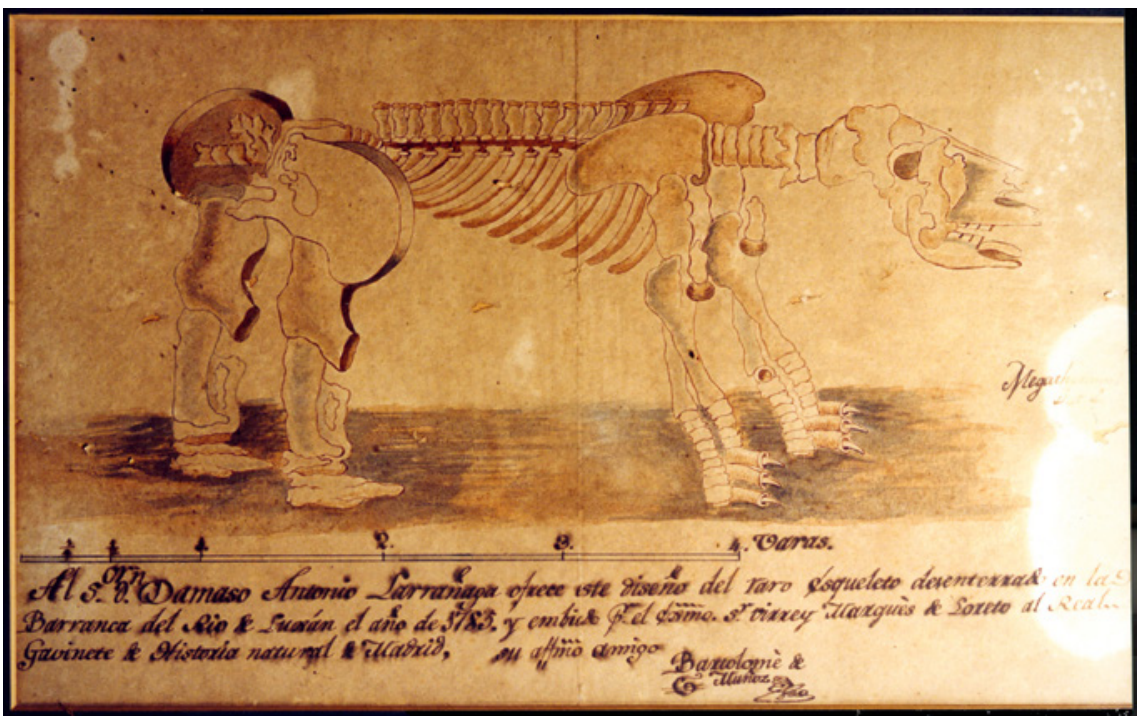

FIGURE 6.2 Copy made by Muñoz of the sketch of the skeleton kept in the archives of Buenos Aires (Archivos Museo de La Plata)

Megatherium. The name was invented specifically to describe its grandeur and to substantiate the idea of "vanished species," which was fundamental to the sciences in the coming century.

The papers that were produced were not only used in the metropolis, but also studied in the Río de la Plata. They were examined by other priests who were interested in the region's natural history, being published for the first time in Buenos Aires in 1835 by the topographer Juan María Gutiérrez (1809-1878) to illustrate an article in Museo Americano, a periodical directed by César Hipólito Bacle (1794-1838), fig. 6.2.

Gutiérrez gave several individuals credit for putting together the skeleton, including the collector, politician and journalist, Joaquín José de Araujo (17621835), whose papers included a copy of the drawing attributed to Brigadier José Custodio de Sá y Faría († 1792), a Portuguese engineer who was very active in marking the borders of the Río de la Plata. Not much is known about the discoverer, the artist, the Indians, and those in charge of mounting the skeleton in Buenos Aires; their names were barely registered in the administration's records. However, these few indicators reveal the type of agents and actions involved in such a discovery: After Dávila's death, the Royal Cabinet continued to gather petrifactions and other items from the three kingdoms of nature sent by individuals who were willing to respond to the requirements of the 1776 instructions. Not only that, as we will see below, the papers created by that 
bureaucracy would lead a parallel life and would end up appearing in the comparative anatomy debates of the 1830 s. $^{17}$

After the dissolution of the Spanish Empire, several colonial bureaucrats and public servants whose work involved producing and safeguarding papers and files, stayed in Buenos Aires and Montevideo, transformed into "civil servants in search of a State," according to the expression coined by Jorge Gelman. ${ }^{18}$ The survival and use of colonial bureaucratic archives and the adaptation of the former technical bodies to the new political order and emerging scientific disciplines of the nineteenth century remains an issue deserving of further research. Thus, the instructions from 1812 together with the attempt to establish a museum in Buenos Aires and the circulation of the drawings and papers related to Megatherium are excellent opportunities to examine both their use and the type of understanding that was being established around the knowledge they generated in the final years of the colonial era. The following section studies a circle of erudite priests, such as Dámaso Larrañaga and Bartolomé Muñoz, involved with the founding of museums and libraries in the Río de la Plata region, and their interaction with French and English and the new publicists who arrived on their shores. Moreover, it studies how, through these priests and their access to old archives, colonial knowledge was introduced into the comparative anatomy debates of the Old World.

On June 27, 1812, the Buenos Aires Revolutionary government gave instructions to compile information on the flora and fauna of the various jurisdictions of the former viceroyalty. The common defence went hand in hand with the promotion of "establishments whose influence, together with the help of all Citizens with a love of good taste, will, when the moment of our sweet emancipation soon comes, also provide the means to attain the level of the Learned Peoples, which the destructive hand of the Peninsular Government

\footnotetext{
17 Irina Podgorny, "El camino de los fósiles: Las colecciones de mamíferos pampeanos en los museos franceses e ingleses," Asclepio 53, no. 2 (2001); Podgorny, "De ángeles, gigantes y megaterios: Saber, dinero y honor en el intercambio de fósiles en las provincias del Plata en la primera mitad del Siglo XIX," in Los lugares del saber: Contextos locales y redes transnacionales en la formación del conocimiento moderno, ed. Ricardo Salvatore (Rosario: Beatriz Viterbo, 2007); Fernando Ramírez Rozzi and Irina Podgorny, "La metamorfosis del megaterio," Ciencia Hoy 11, no. 61 (2001).

18 Gelman, Un funcionario.
} 
had thus far deprived us of."19 The aim was to encourage people to observe the continent's mineral, plant, and animal realms, "which today is without a doubt one of the most worthy occupations of Scholars all around the world, who, enjoying their knowledge and acquisition of the precious talents that are not easily found in our Mother Country, would surely be shocked to find that this, too, we have neglected." These instructions, sent to commanders of the various outposts, sought to establish a museum that would gather together all of the region's rare and unique products that were "worthy of being placed in such a repository, by encouraging all citizens who have them to give them as a gift." For example, in August 1812, an inventory was sent from Concepción in the Misiones province detailing the region's flora and fauna, and promising to send a list of medicinal herbs, "although not all are known." In his response, the commander at Concepción, Celedonio José del Castillo, wrote: "Upon receiving Your Excellency's High Order of 27 June last, I passed it on to the towns in this Department to let everyone know about it, offering the inhabitants to compensate anyone who brought us an animal or some other strange or peculiar thing." ${ }^{20}$ This old colonial practice of hierarchically distributing instructions, from the centre of collection to the people who collected the objects, would live on informally in the traffic consolidated over the course of the nineteenth century of fossils, animals, and artifacts, and formally in museums' instructions to their providers and travelling naturalists. Celedonio del Castillo's response, in remarks concerning the initiatives of the previous administration, contradicted the wording of the instructions.

The instructions of 1812, in addition to seeking to establish a local centre to highlight regional products, set out a collective and integrating enterprise. The museum was to be created with the help of citizens, while at the same time encouraging private individuals to donate whatever oddities they held in their own estates. Thus, in 1813, as a matter of personal pride and patriotic honour, citizen Bartolomé de Muñoz (?-1831), a native of Spain, priest, and vicar general of the army of Montevideo, donated a variety of objects and acquisitions that he had procured for his own private use over a period of "twenty years of trying

\footnotetext{
19 To the Military Commander of Patagones, Buenos Aires, 27 June 1812, Archivo General de la Nación (Buenos Aires). My translation.

20 Del Castillo sent along a list of the "peculiarities" that he himself had come across in his thirty years of living in the area. This included birds, mammals, minerals, plants, medicinal herbs ("there is no single expert who knows them all"), yerba mate plantations ("the mines of this province"), and Araucaria trees ("whose trunks could be used for ships' masts").
} 
diligence."21 Muñoz's gift included a number of maps, dictionaries, Lavoisier's Treatise on Chemistry, "Wiedemann's Treatise on Oryctognosy," as well as natural history objects (a shell collection, natural zoophytes, mineral samples, and prints) and instruments (a microscope, prisms, and a thermometer). ${ }^{22}$

Muñoz's donations reflect the central role that priests, initially inspired by the colonial instructions, played in collecting culture from all over Spanish America. Priests, doctors, and military engineers responded to the government requests; however, motivated by personal interest, love of God or Royal Service, they invested their time and their own resources in purchasing books, scientific instruments, and anything else they needed to carry out the work and keep up to date with advances in the field of natural history. The instructions from 1812 are striking in terms of the clear confidence placed in the institution, and in its utilitarian conception. The museum, far from emerging as an institution governed by a council of the wise, issued the instructions to gather the objects. The same people taking part in the national government - people trained in the army or in law and colonial administration - would decide how to archive and classify the information coming in from the various jurisdictions and command headquarters of the districts of the River Plate region. This initiative did not prosper, and the individual collections continued to exist, albeit disconnected from both the viceroy's instructions and the failed revolutionary ones. A historiography that favours the notion of Spanish isolation and darkness has treated these collections as mere personal initiatives, forgetting that they also grew out of the attempts to coordinate them by first the metropolitan and, then, the revolutionary government.

In this context, the priests Dámaso A. Larrañaga (1771-1848) and again Bartolomé D. Muñoz stand out as avid readers and consumers of the books that, through different agents, arrived from Europe and from Rio de Janeiro. ${ }^{23}$ The interest was such that European visitors filled their suitcases with the novelties published in Paris and London, sure to be able to sell them at a good

21 Muñoz, quoted in Irina Podgorny and Maria Margaret Lopes, El desierto en una vitrina: Museos e historia natural en la Argentina, 1810-189o (Mexico: Limusa, 2008), 36.

22 Muñoz sent his donation in a trunk in September 1813, and in October it was transferred to the library, where it was noticed that some items were missing. The donation was officially accepted in 1814 .

23 Roberto Di Stéfano, El púlpito y la plaza: Clero, sociedad y política de la monarquía católica a la república rosista (Buenos Aires: Siglo XXI, 2004). Rio de Janeiro was the headquarters of the Portuguese court and as such, housed a natural history cabinet; see Maria Margaret Lopes, O Brasil descobre a pesquisa científica: Os museus e as ciências naturais no século XIX (São Paulo: Hucitec, 1997). 
profit. ${ }^{24}$ Collectors of manuscripts, devices and instruments, meteorological observations, plants, petrified objects and animals, the clerics exchanged data, papers, and drawings. After 1810 and the break with Spain, many of these religious men would divide their time between their commitment to revolution and their endeavours as naturalists. They were put in charge of the public libraries in Buenos Aires and Montevideo (1816) and/or museums or the initiatives to create them. While Muñoz, with patriotic zeal, donated his collections to establish a museum that never opened its doors, Larrañaga's private collections would attract all those interested in the past and future of these regions. They both compiled, read, translated and copied drawings and manuscripts, accumulating and organizing a vast corpus of documentary materials. They also extracted articles from the many books they purchased. ${ }^{25}$

Larrañaga, in particular, had a special predilection for plants: the world of the Bourbons had heightened awareness among clerics and pharmacists as to the benefits of studying texts on the medicinal properties of indigenous plants in the Americas and the potential for boosting the economy by capitalizing on the country's fruits and vegetables. ${ }^{26}$ The Flora Peruana, or the plant collections of the botanists from the expedition of Alejandro Malaspina, arrived in Buenos Aires, not necessarily in book form, but rather through the accounts and manuscript copies that were gathered and transcribed from the collections of the region's curates. This copyist culture, forming as it did part of the clergy's education, shaped the study of natural history, in which the new methods of observation were combined with the practices of reading and extracting notes from manuscripts and printed materials. These priests drafted various treatises on natural history in dictionary form, bringing together different points of view organized in alphabetical order in booklets, embracing the many innovations that they added with each new reading. They also prepared tableaux,

24 So, when Aimé Bonpland (1773-1858) arrived in Buenos Aires in 1816, in addition to various commercial endeavours that he had in mind, he brought an enormous collection of books on natural history that he offered to collectors and to libraries in Buenos Aires, Santiago de Chile, and Montevideo. See Stephen Bell, A Life in Shadow: Aimé Bonpland in Southern South America, 1817-1858 (Palo Alto: Stanford University Press, 2010).

25 Among others: the Encyclopaedia Britannica, or A dictionary of arts, sciences, and miscellaneous literature; enlarged and improved (Edinburgh, 1810), the Dictionnaire d'Histoire Naturelle (Paris, 1804), the Florae peruvianae et chilensis by Hipólito Ruiz and José Pavón (Madrid, 1794), the 13th edition of Carl Linnaeus's Systema Naturae, published between 1788 and 1793 by Johann Friedrich Gmelin, the natural histories of Félix de Azara and of Georges L. Leclerc, count of Buffon.

26 Rafael Algorta Camusso, El Padre Dámaso Antonio Larrañaga: Apuntes para su Biografía (Montevideo, 1922); Fernando Mañé Garzón, El Glorioso montevideano: Vida y obra del Doctor José Manuel Pérez Castellano (1742-1815) (Montevideo, 1998-2003). 


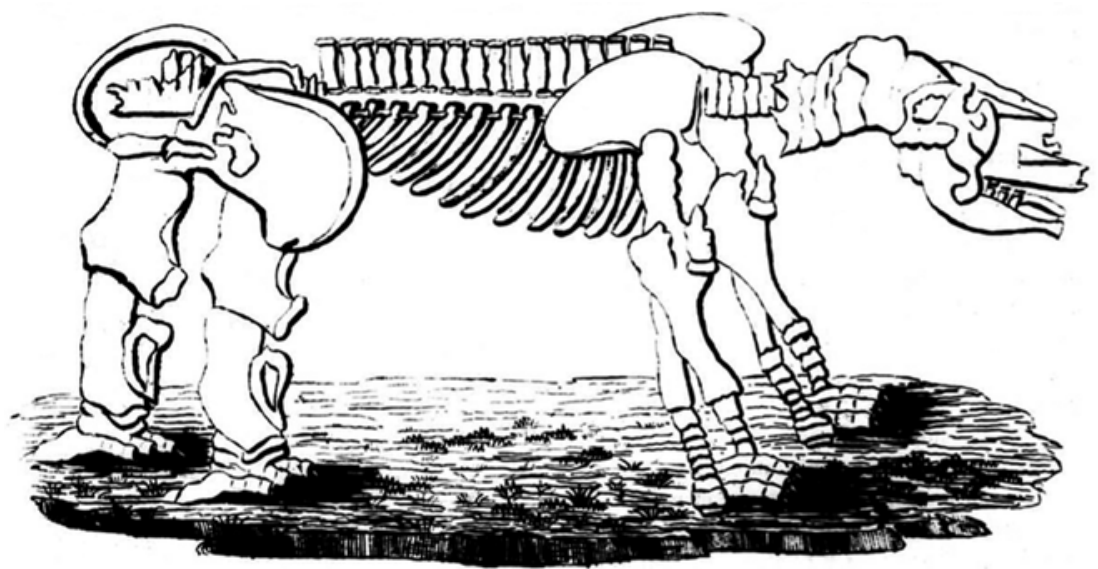

FIGURE 6.3 The colonial sketch as published in El Museo Americano

classification tables for the zoology, botany and mineralogy of the country, which were amended with the inclusion of new specimens. Furthermore, they illustrated and coloured their observations. Flowers, insects and birds sprang back to life through the clergy's ink.

One such drawing that they copied from the colonial archives in Buenos Aires, was the aforementioned colossal skeletal figure, when Larrañaga recorded in his journal in 1814 a new discovery of "bones of Megatherium." He subsequently translated a description published in the Encyclopaedia Britannica in 1810 that emphasised the paradoxical nature of this beast and an English article from 1806 that discussed the similarities of the animal to sloths and elephants. Muñoz, in copying the drawing from the Buenos Aires archive, omitted the description of the brigadier to instead note that the beast was now known as "megatherium," (fig. 6.3)

Hence, through the colonial archives and publications, they became aware of the debates about the controversial zoological affinity of this entity. From 1808 on, these priests devoted themselves to the study of comparative anatomy and to the classification of mammals, combining various systems with their observations and those of former colonial Spanish military engineers. In the early 1820 s Larrañaga was convinced that the animal from Luján could have had a shell similar to that of the armadillos.

Larrañaga displayed his collections in the house-museum on his family's property, where he received several travelling captains and naturalists, to whom he would show his most precious objects and engage in debate. These visitors, who included Aimé Bonpland, the French botanist Auguste Saint-Hilaire (1779-1853), and Friedrich Sellow (1789-1831), commissioned 
by the Portuguese and Prussian court to collect samples from the provinces of Rio Grande do Sul and Uruguay were responsible for disseminating the views of Larrañaga to ever widening circles. In Larrañaga's museum, Sellow and Saint-Hilaire saw fragments of a bony coat of mail or tessellated armour, belonging to the back and tail of a very large animal. Seizing upon the clergyman's ideas, they reported to Berlin and Paris that these pieces likely belonged to Megatherium. Thus began a disagreement about the anatomy of this burly animal that lasted almost twenty years and reveals the impact of oral tradition on the culture of natural history. The conversations and readings went back and forth continuously to and from Montevideo, Buenos Aires or Asunción, by way of different ports and cities, where other meanings were ascribed to them before they continued on their way. ${ }^{27}$

\section{4 Some Final Considerations}

The history of instructions as a form of long-distance governance, as a mechanism to educate and oversee the gestures and observation of the traveller, or to assure "immutable mobiles" is not a new story. ${ }^{28} \mathrm{It}$ is not an innovation of the Bourbons or the Enlightenment, much less of the nineteenth century or the new American republics. Instructions, on the contrary, reveal a long history that transcended administrative reforms, revolutions, and breaks in the political order. Once the Spanish Empire had fallen, its former subjects continued behaving in the same way. Perhaps because of that, the history of the papers related to the Megatherium is repeated with other names and objects throughout America. Its population of former civil servants, priests, and topographers from Peru, New Grenada, New Spain and the River Plate had access to the colonial archives, worked with the data they found there, and began to write about the history and natural history of their regions. In addition, they had contact with agents who made copies or simply purchased their documents to have them translated and published in France and England, rediscovering that which, as the very papers testify, had been described decades before. ${ }^{29}$

27 On these debates, see Irina Podgorny, "Fossil Dealers: The Practices of Comparative Anatomy and British Diplomacy in Latin America, 1820-1840," The British Journal for the History of Science 46, no. 4 (2013).

28 Bruno Latour, "Visualisation and Cognition: Drawing Things Together," in Knowledge and Society: Studies in the Sociology of Culture Past and Present: a Research Annual 6 (1986): 140.

29 The colonial bureaucracy produced an enormous load of documents in original and copy. Until late in the 18th century, all the documentation regarding the overseas empire 
This process of dispersal of data - which some call accumulation - happened at the same time as the establishment throughout America of institutions either as replacements for colonial ones or as brand new ones. With a difference of very few years, the various governments or collectors with the resources to do so began to establish public museums. The dates indicate trends or waves that cannot be explained by the metropolitan dispositions such as those promoted in the context of the late eighteenth-century expeditions and the Catholic - or Protestant - Enlightenment that, according to the now classic expression of José Carlos Chiaramonte, characterized the late colonial American world. Many of these collections, such as those of Franco Dávila grew out of the mix between commercial culture, the worldly passion of the Enlightenment for science and nature, and the trade expectations of the new republics. Wherever there was an important port, an initiative appeared to compile and gather the products that, in some way or another, passed through it, to exhibit and inventory them as in a storefront.

Historiography has treated the years around 1810 and the growth of new independent nations as the point of origin from which each Latin American nation began to construct its own identity and destiny. A less hasty examination reveals a political, social, and economic panorama filled with ambiguity, contradictions, confusions, and of course ruptures, but also continuities. The breaks are evident: for example, the key issue of how to rebuild finances, the foundation of any political and administrative structure. ${ }^{30}$ However, in the majority of cases, continuity predominates: individuals continued doing what they had learned how to do; for a long time, offices continued using the same stationary, barely covering the official stamp of Ferdinand viI.

The establishment of museums and cabinets in the new nations is linked to these historical events and to the expansion of the new scientific disciplines that occurred almost in parallel. The fall of Spain, the French Revolution, and

was dispersed among various archives, as Simancas, Cádiz and Seville in Spain and the local administrative offices in the Americas, which housed copies and the documents needed for administration. In Spain, the Archivo General de Indias established in 1785, brought together the documentation existing in Spain. A similar initiative followed in Mexico, where the General Archive of Chapultepec was established in 1792. In the Rio de la Plata, until the creation of the Archive of Buenos Aires in 1821, papers were kept at the respective administrative offices, such as the Cabildo, the Tribunal del Consulado, and the Contaduría General. For a general bibliography on the topic, see Irina Podgorny, "Los archivos: Entre el síndrome de Barba Azul y los sueños de Napoleón," in Los secretos de Barba Azul: Fantasías y realidades de los archivos del Museo de La Plata, ed. Tatiana Kelly and Irina Podgorny (Rosario: Prohistoria, 2012).

30 Tulio Halperín Donghi, Guerra y finanzas en los orígenes del Estado argentino, 1791-1850 (Buenos Aires: Universidad de Belgrano, 1982). 
the North Atlantic War of 1812 provoked the mobilization of an enormous quantity of data that flooded the most diverse spaces. The materials gathered in the cabinets of the new Hispanic world, Madrid, or Portugal through confiscation and the traffic of drawings and documents, would shape the new disciplines of herpetology, malacology, comparative anatomy, palaeontology, and archaeology. This dispersion, combined with the access and circulation of the reports, maps, and drawings of expeditions and of colonial military engineers, implies various things: on the one hand, the rupture of an administrative order based on both the copious production of papers and documents and limited access to its archives, and on the other, the admittance of those data into the new disciplines of the nineteenth century. Thus, the materials produced in the eighteenth century, that had until that point remained in the circuit of the colonial American administration or accumulated in the office of the general Cosmographer of the Indies, are taken out of that order to enter into the socalled "spirit of the system" of nature and history, characterized by its dynamism, the reformulation of its categories, and permanent debate.

\section{Acknowledgements}

Earlier versions of this paper - written in the frame of the Research Projects PIPCONICET O153, and PICT 20153534 on "The Bureaucracy of Knowledge" - were discussed in several opportunities and workshops. I would like to thank María Jesús Santesmases, Mark Thurner, and Annick Lempérière, whose comments as well as the help of the ILL service from the M PIWG Berlin were much appreciated. A version of the chapter was previously published in a similar form: "Bureaucracy, Instructions, and Paperwork: The Gathering of Data about the Three Kingdoms of Nature in the Americas, 1770-1815." Nuevo Mundo Mundos Nuevos [Online], Paper posted on February 19, 2019. https://doi.org/10.400o/ nuevomundo.75454. I would also like to thank Simona Boscani Leoni, Meike Knittel, and Sarah Baumgartner for the fruitful discussions during the Bern conference and the preparation of this volume.

\section{Bibliography}

Algorta Camusso, Rafael. El Padre Dámaso Antonio Larrañaga: Apuntes para su biografía. Montevideo: Barreiro y Ramos, 1922.

Barreiro, Agustín Jesús. El Museo Nacional de Ciencias Naturales (1771-1935). Madrid: Doce Calles, 1992 (1944). 
Bell, Stephen. A Life in Shadow: Aimé Bonpland in Southern South America, 1817-1858. Palo Alto: Stanford University Press, 2010.

Bourguet, Marie-Noëlle. "La collecte du monde: Voyage et histoire naturelle (fin XVII ${ }^{\text {ème }}$ siècle - début XIX ème siècle)." In Le Muséum au premier siècle de son histoire, edited by Claude Blanckaert, Claudine Cohen, Pietro Corsi and Jean-Louis Fischer, 163-96. Paris: Muséum national d'Histoire naturelle, 1997.

Brendecke, Arndt. Imperium und Empirie: Funktionen des Wissens in der Spanischen Kolonialherrschaft. Cologne: Böhlau, 2009.

Calatayud Arinero, María Ángeles. Catálogo crítico de los documentos del Real Gabinete de Historia Natural (1787-1815). Madrid: CSIC, 2000.

Constantino, María Eugenia and Antonio Lafuente. "The Hidden Logistics of Longinos's Novohispanic Cabinet." Nuncius 27, no. 2 (2012): 348-70.

Di Stéfano, Roberto. El púlpito y la plaza: Clero, sociedad y política de la monarquía católica a la república rosista. Buenos Aires: Siglo Veintiuno, 2004.

Figueroa, Marcelo F. "Packing Techniques and Political Obedience as Scientific Issues: 18th-Century Medicinal Balsams, Gums and Resins from the Indies to Madrid." HOST 5 (2012): 49-67.

Gaudin, Guillaume. Penser et gouverner le nouveau monde au XVII siècle: l'empire de papier de Juan Díez de la Calle, commis du Conseil des Indes. Paris: L'Harmattan, 2013.

Gelman, Jorge. Un funcionario en busca del Estado: Pedro Andrés García y la cuestión agraria bonaerense, 1810-1822. Buenos Aires: Universidad Nacional de Quilmes, 1997.

Grieco, Viviana L. The Politics of Giving in the Viceroyalty of Rio de la Plata: Donors, Lenders, Subjects, and Citizens. Albuquerque: The University of New Mexico Press, 2014 .

Halperín Donghi, Tulio. Guerra y finanzas en los orígenes del Estado argentino, 17911850. Buenos Aires: Universidad de Belgrano, 1982.

Latour, Bruno. "Visualisation and Cognition: Drawing Things Together." Knowledge and Society: Studies in the Sociology of Culture Past and Present: a Research Annual 6 (1986): 1-40.

Lemoine Villicaña, Ernesto. "Instrucciones para aumentar las colecciones del gabinete de historia natural de Madrid." Boletín del Archivo General de la Nación 2 (1961): 189-23o.

Lopes, María Margaret. O Brasil descobre a pesquisa científica. Os Museus e as ciências naturais no século XIX. São Paulo: Hucitec, 1997.

López Piñero, Jose María. El arte de navegar en la España del Renacimiento. Madrid: Labor, 1979.

Lleó Cañal, Vicente. "Julian Benjamin Williams y el comercio de arte en la Sevilla del XIX." Boletín de la Real academia Sevillana de Buenas Letras: Minervae Baeticae 36 (2008): 187-204. 
Mañé Garzón, Fernando. El Glorioso montevideano: Vida y obra del Doctor José Manuel Pérez Castellano (1742-1815). Montevideo: Archivo General de la Nación, 1998-2003.

Pimentel, Juan. Testigos del Mundo: Ciencia, literatura y viajes en la ilustración. Madrid: Marcial Pons, 2003.

Podgorny, Irina. "Fossil Dealers, the Practices of Comparative Anatomy and British Diplomacy in Latin America, 1820-1840." The British Journal for the History of Science 46, no. 4 (2013): 647-74.

Podgorny, Irina "Los archivos: Entre el síndrome de Barba Azul y los sueños de Napoleón." In Los secretos de Barba Azul: Fantasías y realidades de los archivos del Museo de La Plata, edited by Tatiana Kelly and Irina Podgorny, 21-39. Rosario: Prohistoria, 2012.

Podgorny, Irina. "El camino de los fósiles: Las colecciones de mamíferos pampeanos en los museos franceses e ingleses." Asclepio 53, no. 2 (2001): 97-116.

Podgorny, Irina. "The reliability of the ruins." Journal of Spanish Cultural Studies 8, no. 2 (2007): 213-33.

Podgorny, Irina. "De ángeles, gigantes y megaterios. Saber, dinero y honor en el intercambio de fósiles en las provincias del Plata en la primera mitad del Siglo XIX." In Los lugares del saber. Contextos locales y redes transnacionales en la formación del conocimiento moderno, edited by Ricardo Salvatore, 125-57. Rosario: Beatriz Viterbo, 2007.

Podgorny, Irina. "Bureaucracy, Instructions, and Paperwork: The Gathering of Data about the Three Kingdoms of Nature in the Americas, 1770-1815." Nuevo Mundo Mundos Nuevos [Online], Paper posted on February 19, 2019, accessed on 21 June 2021. https://doi.org/10.400o/nuevomundo.75454.

Podgorny, Irina and Maria Margaret Lopes. El desierto en una vitrina: Museos e historia Natural en la Argentina, 1810-189o. Mexico: Limusa, 2008.

Podgorny, Irina and Wolfgang Schäffner. "La intención de observar abre los ojos." Prismas, 4 (2000): 217-27.

Ramírez Rozzi, Fernando and Irina Podgorny. "La metamorfosis del megaterio." Ciencia Hoy 11, no. 61 (2001): 12-19.

Safier, Neil. Measuring the New World: Enlightenment Science and South America. Chicago, London: The University of Chicago Press, 2008.

Sánchez Almazán, Javier I. Pedro Franco Dávila: De Guayaquil a la Royal Society. La época y la obra de un ilustrado criollo. Madrid: csic, 2012.

Shapin, Steven and Simon Schaffer. Leviathan and the Air-Pump: Hobbes, Boyle, and the Experimental Life. Princeton: Princeton University Press, 1985.

Schäffner, Wolfgang. "Die Verwaltung der Endlichkeit. Zur Geburt des neuzeitlichen Romans in Spanien." In Die Endlichkeit der Literatur, edited by Eckart Goebel and Martin von Koppenfels, 1-12. Berlin: Akademie Verlag, 2002. 
Siegert, Bernhard. Passagiere und Papiere: Schreibakte auf der Schwelle zwischen Spanien und Amerika. Munich: W. Fink, 2006.

Socolow, Susan. The Bureaucrats of Buenos Aires, 1769-1810: Amor al Real Servicio. Durham, London: Duke University Press, 1987.

Stagl, Justin. Apodemiken:Eine räsonnierte Bibliographie der reisetheoretischen Literatur des 16., 17. und 18. Jahrhunderts. Paderborn: Schöningh, 1983.

Tanner, Jakob. “Akteure, Akten und Archive." In Was Akten bewirken können: Integrations- und Ausschlussprozesse eines Verwaltungsvorgangs, edited by Claudia Kaufmann and Walter Leimgruber, 150-6o. Zurich: Seismo, 2008.

Trelles, Manuel R. "El Padre Manuel de Torres." Revista de la Biblioteca Pública de Buenos Aires 4 (1882): 439-48.

Villena Sánchez-Valero, Miguel, Javier I. Sánchez Almazán, Jesús Muñoz Fernández, and Francisco Yagüe Sánchez. El gabinete perdido. Pedro Franco Dávila y la Historia Natural del Siglo de las Luces. Madrid: CSIC, 2009. 